\title{
Overgangstypen til den moderne homoseksuelle
}

\section{Den »usynlige « forfatter Carl Markman (1840-1894)}

\author{
Af Wilhelm von Rosen
}

Carl Markman tilhørte en generation af mœnd, som var for gamle til at blive rigtigt moderne homoseksuelle. Da denne rolle kom til at foreligge i Danmark i 1870' erne og 1880' erne, blev han af yngre homoseksuelle mœnd i samtiden alligevel regnet for at vœre homoseksuel.

Wilhelm von Rosen beskriver den offentlig kendte forfatter Carl Markmans liv og stiller det spørgsmål, om han var homoseksuel. Offentligheden vidste ikke noget om Markmans seksualitet, og de yngre homoseksuelle vidste i virkeligheden heller ikke noget. Hvad vidste Markman selv? Var han en Pontus Wikner uden selvbekendelser?

Artiklen illustrerer de begrebsmæessige og metodiske problemer, der er forbundet med historieskrivningens forsøg på at synligg øre »det usynlige«.

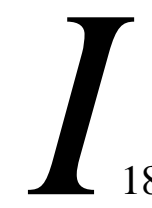

1850'erne og 1860'erne stod tiden endnu forholdsvis stille i Danmark; det gamle begreb fra

Danske Lov, »omgœngelse imod naturen« (sodomi), var endnu ikke forœldet; i den nye straffelov af 1866 hed det stadig »omgœngelse imod naturen«. Denne fœlles betegnelse for omgœngelse med et dyr (bestialitet) og med en mand (pœederasti) var fortsat en meningsfuld og brugbar strafferetlig kategori. Der var pœderaster i København, men de var fåtallige i forhold til en senere tids homoseksuelle, og de bemærkedes ikke af andre end nogle få politifolk og dommere. Pœderasterne blev endnu ikke sat i forbindelse med nœre venskaber mellem mœnd, med mœnds œgteskabslignende samliv og kvindagtighed.

I 1851 var de to 30årige fuldmœgtige i Justitsministeriet, Carl Høegh-Guldberg og Molt Wengel, flyttet sammen. En af deres venner fra det studenterforeningsmiljø, hvori de fœrdedes, berettede senere om dem: »For enhver, der har kjendt disse to elskvœrdige Mennesker, staa de som uadskilligt knyttede til hinanden. De boede sammen og var nœsten altid sammen. Hvor forskjellige de end vare, saavel i Ydre som i Indre, dannede de, maaske netop ved at supplere hinanden, en Enhed, som om det havde vœret et Ægtepar«. Der var i Guldbergs vœsen »noget kvindeligt, der gjorde, at han var saa aldeles uforlignelig, naar han spillede Dameroller«. (...)»I deres fœlles Husholdning var det Wengel, der var Manden, Guldberg, der var Konen; men jeg tør ikke paastaa, at Manden ikke var en Smule under Tøffelen«. 1 skildringen af dette vennepar, der boede sammen til Wengels død i 1859, antydes ikke noget seksuelt.1

Det var stilhed før stormen. I 1840'erne og 1850'erne blev der fra forskellig side fremlagt en rœkke vidt forskellige modeller til nœrmere at forklare de mœrkvœrdige pœderaster; der mœrkedes en »efterspørgsel« efter en forklaring, som gik videre end til at anse pœderasti for at vœre en tilfœldig umoralsk handling.2 Det blev lœgernes og pœderasternes forenede hypotese om homoseksualitet som et 
medfødt degenerationstegn - der indebar et argument for straffrihed - som kom til fuldstœndigt at dominere i de følgende hundrede år.

\section{Overgangen fra pœederast til homoseksuel}

Pœderasternes og lœgernes fœlles forestillinger om, at de, som havde sex med deres eget køn, var en sœrlig slags mennesker - urninge, kontrœrseksuale og homoseksuelle - udformedes i Tyskland i 1860'erne. Denne udvikling nåede gradvist til Danmark i løbet af 1870'erne og 1880'erne. Men en af de danske, som jœvnligt fœrdedes i udlandet, H.C. Andersen, havde inden da et angstprovokerende møde med fremtiden, da han i 1860 i en alder af 55 år, i Geneve blev ops $\emptyset$ gt af den 36årige østrig-ungarske førfatter og oversætter, Karl Maria Kertbeny. Deres møde og de efterfølgende forviklinger - af H.C. Andersen-forskeren H. Topsøe-Jensen betegnet »Kertbeny-affæren« - har et skær af besynderlighed og uforklarlighed over sig.3 Hvorfor følte Andersen sig straks »uhyggelig ved den iøvrigt høist aandrige og venlige Mands Besøg «?4 Var der en sammenhæng mellem deres møde og Andersens samtidigt indtrådte depression?5 Hvorfor havde Kertbeny et så ilde ry i litterrære kredse i München og Leipzig?6 Selv tilskrev Andersen »denne uhyggelige Følelse « sin »Angest for at omgaaes politiske Personer, maaskee her aldeles ugrundet «7 På sin vis var, eller rettere blev, Kertbeny en politisk person, en af pionererne i den europeiske homoseksuelle emancipationsbevœgelse og i 1869 opfinder af ordet »homoseksuel«.8 Selvom det skete, mens Andersens endnu levede, var der tale om en anden tid end Andersens; hans møde med Kertbeny var et møde mellem to tidsaldre og to meget forskellige bevidstheder om mœnd, der forelskede sig i mœnd. 9

I 1870 publiceredes i Danmark et uddrag af nervelœgen C.F.O. Westphals skelsættende afhandling om den kontrœre seksualfornemmelse i »Bibliothek for Lœger«, og i 1880 omtalte overlœge Rudolph Bergh »disse Pederaster, de saakaldte »Urninge««. Han bemœrkede, at Karl Heinrich Ulrichs - »denne utrœttelige Forkjœmper for disse andromane Individer « - anslog antallet af urninge til 1 ud af 200 for Tysklands vedkommende. Det var i Berghs øjne meget overdrevet og gjaldt efter hans mening ikke for Danmark.10 Først i slutningen af 1880'erne og i 1890'erne blev der i Danmark publiceret medicinske afhandlinger om homoseksualitet.

Endnu i 1888 kunne fœngselsprœsten ved Horsens Straffeanstalt, S.M. Hafstrøm konstatere, at »i den danske Nationalkarakter have de unaturlige Forbrydelser og de vœrste Vildskud af Kjønsdriften vist ikke dybe Rødder«,11 og endnu i 1896 kunne en œldre herre mindes sin ungdoms venner, Carl HøeghGuldberg og Molt Wengel, og spøgefuldt beskrive dem på en måde, der må have forekommet yngre lœsere at vœre rørende naiv og troskyldig. Men en ny virkelighed trœngte sig på. I en forelœsning i 1891 om »Pervers Seksualitet« udtalte overlœge, docent i psykiatri, Knud Pontoppidan, om sådanne nœre venskabsforhold:

De kender vist alle Eksempler paa den Slags unaturlige Forhold mellem to Mennesker af samme Køn, Forbindelser, hvor der rimeligvis aldrig har vœret Tale om perverse Actus, men som dog holdes sammen ved saa varme Følelser, at vi faa en bestemt Formodning om pervers Seksualitet som Grundlag. (...) Jeg er tilbøjelig til at tro, at hvis der gives mig Lejlighed til at trœnge ind i et saadant Tilfœldes Natur, vil jeg som Regel kunne paavise, at Fœnomenet optrœder sammen med andre neuropatiske Symptomer paa et fœlles degenerativt Grundlag.12

Disse bemœrkninger faldt i en frugtbar jord, og de markerede, at fra 1800-tallets slutning var det ikke lœngere kun den genitalseksuelle handling - omgœngelse mod naturen (pœderasti) - der fordømtes. Det blev nu en hertil knyttet abnorm tilstand og et tilhørende sœrligt følelsesliv, der blev interessant som årsag til handlingen og socialt marginaliseret som en sygdom. Kom det til en »Forbrydelse«, var den med Knud Pontoppidans ord -betinget af »en afgjort sygelig, medfødt og efter sin Natur uhelbredelig Abnormitet «.13

Dette indebar en voldsom œndring af holdninger. Mistanken om, at varme følelser og nœre forhold mellem mœnd kunne vœre 
Danmark.10 Først i slutningen af 1880'erne og i 189O'erne blev der i Danmark publiceret medicinske afhandlinger om homoseksualitet.

Endnu i 1888 kunne fœngselsprœsten ved Horsens Straffeanstalt, S.M. Hafstrøm konstatere, at »i den danske Nationalkarakter have de unaturlige Forbrydelser og de vœrste Vildskud af Kjønsdriften vist ikke dybe Rødder«,,ll og endnu i 18\% kunne en œldre herre mindes sin ungdoms venner, Carl Høegh-Guldberg og Molt Wengel, og spøgefuldt beskrive dem på en måde, der må have forekommet yngre lœsere at vœre mœnde naiv og troskyldig. Men en ny virkelighed trœngte sig på. I en forelœsning i 1891 om »Pervers Seksualitet« udtalte overlœge, docent i psykiatri, Knud Pontoppidan, om sådanne nœre venskabsforhold:

De kender vist alle Eksempler paa den Slags unaturlige Forhold mellem to Mennesker af samme Køn, Forbindelser, hvor der rimeligvis aldrig har vœret Tale om perverse Actus, men som dog holdes sammen ved saa varme Felelser, at vi faa en bestemt Formodning om pervers Seksualitet som Grundlag. (...) Jeg er tilbejelig til at tro, at hvis der gives mig Lejlighed tiI at trœnge ind i et saadant Tilfœldes Natur, vii jeg som Regel kunne paavise, at Frenomenet optrœder sammen med andre neuropatiske Symptomer paa et folles degenerativt Grundlag.12

Disse bemœrkninger faldt i en frugtbar jord, og de markerede, at fra 1800-tallets slutning var det ikke lœngere kun den genitalseksuelle handling - omgœngelse mod naturen (pœderasti) - der fordømtes. Det blev nu en hertil knyttet abnorm tilstand og et tilhørende sœrligt følelsesliv, der blev interessant som årsag fil handlingen og socialt marginaliseret som en sygdom. Kom det til en »Forbrydelse«, var den med Knud Pontoppidans ord - betinget af »en afgjort sygelig, medfødt og efter sin Natur uhelbredelig Abnormitet «.13.

Dette indebar en voldsom œndring af holdninger. Mistanken om, at varme følelser og nœre forhold mellem mœnd kunne vœre et udslag af abnormitet og sindssyge, gjorde tidligere begreber om inderligt venskab - som f.eks. H.C Andersen havde udtrykt dem i 1830'erne - socialt mistœnkelige. I 1893 sattes den nu afdøde H.C Andersen for første gang offentligt i forbindelse med sœdelighedsforbrydelser mod smådrenge.14 Denne udvikling medførte, at moralsk afsky for pœderasti suppleredes med personlig angst. Det litterrere eksempel var Johs.V. Jensens paranoide roman »Hjulet« (1905) om den megalomaniske homoseksuelle skurk og religionssvindler, Cancer. Følelser mellem mœnd blev nu forstået og forklaret som homoseksualitet, et ud slag af en sœrlig tilstand, en perversion. Hertil svarede en opståen af homoseksuel identitet. 15 Den, som begik omgœngelse imod naturen, den som drev pœderasti, havde vœret et retssubjekt; den homoseksuelle blev - som bemœrket af Michel Foucault - en personlighed med en fortid, en historie, en barndom, en karakter og en livsstil. Intet af hans vœsen undslap hans homoseksualitet. Den var tilstede overalt i ham og lå til grund for hans handlinger, »fordi den er deres underfundige og ustandselige aktive princip, ublufœrdigt indskrevet på hans ansigt og på hans legeme fordi den er en hemmelighed som uophøfligt røber sig. Homoseksualiteten er hele den homoseksuelles vœsen, mindre som en vanesynd end som en enestående natur«. Denne natur tilhørte og var det dybeste kendemœrke for en sœrlig menneskeklasse, en art.16

I 1912 - det år forfatteren Herman Bang døde - var de homoseksuelles eksistens i Danmark blevet en uafviselig kendsgerning i offentligheden og et samfundsproblem af dramatiske proportioner. Der var året før, i 1911, blevet afholdt et stort »Borgermøde om Homosexualisme« i koncertpalœet i København.17 Lœge Emanuel Frœnkel skrev herom: »Befolkningen var bleven opskrœmmet over de homosexuelle Epidemier og over den Maade, hvorpaa Autoriteterne tog paa de homosexuelle Udskejelser «. 18 Det svarede til denne forandring i udviklingen af synet på sex mellem mœnd fra 1860'erne til århundredskiftet, at der i Danmark som i Europa (måske sœrligt i Nordeuropa) opstod en art af mennesket, som ikke havde vœret der før.19 Hvordan blev denne første generation af homoseksuelle i Danmark til homoseksuelle, hvordan oplevede de det, og hvordan forløb denne proces? Hvem blev udpeget som homoseksuelle eller tog på sig at vœre det? Historien kan kun pege på de konkrete sociale og kulturelle omstœndigheder og på de biografiske begivenheder. I enkelte tilfœlde kan homoseksuelles selvbiografiske udtalelser meddele og karakterisere deres egne konklusioner på baggrund af introspektion og erindring. Den bevidsthed, der afspejles her, viser sig at vœre om ikke fuldt, så dog 
nœrt overensstemmende med mange ikke-homoseksuelles og med lœgevidenskabens forståelse af den homoseksuelle. Den prototypiske homoseksuelle mand i dansk bøssehistorie, Herman Bang, skrev i 1893 til sin svoger: »Hvis du vidste hvad det vil sige at slœbe paa denne forbandelse gennem livet. (...) Vi, som fra fødselen slœber paa denne sygdom - thi det er en sygdom, selvom du ikke vil tro det «, (...) 20 Denne sygdom og forbandelse måtte bringes til ophør, og Bang skrev mod slutningen af sit liv: »Det er i statens interesse, at homoseksualitet udforskes videnskabeligt, for at der kan findes veje til at begrœnse eller udslette den; alene hensynet til forplantningen krœver indstœndigt en sådan begrœnsning«.21

Forud for denne symbiose mellem pœderasterne - der nu var homoseksuelle - og lœgevidenskaben om, hvad homoseksualitet var, nåede den amerikanske digter Walt Whitman i 1860 med Calamusdigtene i 3. udgaven af »Leaves of Grass « at formulere et alternativ. Hans fornemmelse af den samfundsmœssige betydning af mœnds kœrlige og erotiske følelser for mœnd indeholdt visionen om en kommende moderne, demokratisk og amerikansk manderolle. Denne profeti, der indebar et historisk alternativ til den homoseksuelle rolle, fik imidlertid ikke foreløbigt nogen fremtid, fordi den vurderede disse følelser som positive, både individuelt og socialt.

\section{De første usynlige homoseksuelle}

Uden at kende Ulrichs' skrifter - eller den whitmanske vision - nåede den svenske forfatter og filosof Pontus Wikner (1837-1888) i 1870' erne til den samme konklusion som Ulrichs om sit sœrlige vœsen som menneske. Wikners kønslige tilbøjelighed for drenge og unge mœnd var hans »virkelige natur«, et »kœrlighedsbehov« hinsides hans frie vilje og uudryddelig som andre mœnds tilbøjelighed for kvinder. Hans bekendelsesskrift herom, hans »psykologiska självbekännelser«, blev nedskrevet i 1879. Wikners hensigt var emancipatorisk; det var hans udtrykkelige ønske, at skriftet blev offentliggjort efter hans død. »I loger og I lovgivere, jeg besvœrger Eder ved alt, hvad I holder helligt, at I bringer hjœlp til mine brødre«. Hans beskrivelse af sin natur, tilbøjeligheder, forelskelser og nogle tilfœlde af »såkaldt sodomitteri (gensidig onani)« i ungdommen er et bemœrkelsesvœrdigt eksempel på, at tanken om det sœrlige homoseksuelle menneske opstod hos flere på omtrent samme tid og uafhœngigt af hinanden.22 Det gjaldt for Wikner som for nœsten alle i de føfste årgange af homoseksuelle mœnd, at de var »usynlige«. De få homoseksuelle, som vi har kendskab tilfra denne tid, blev nœsten alle på en eller anden måde afs1øret i deres samtid. Derfor foreligger der kilder til deres biografi i aviser, i retsakter og i breve. I det følgende fortœlles om en mand, Carl Markman, der levede fra 1840 til 1894. Han blev ikke afs1øret som homoseksuel. Men der var homoseksuelle, som troede eller måske vidste, at Markman var homoseksuel. På den måde bliver han i historiens øjne en »usynlig « måske-homoseksuel mand.

Den første generation af danske homoseksuelle fødtes i 1850'erne, var studenter og blev voksne i 1870' erne. De prœgedes i deres ungdom af modernismens gennembrud og af denne periodes strid om fritœnkere, om videnskaben som vejen til at forstå verden, om realismen i litteraturen og om kønsdriften. Forfatteren Karl Larsen (født 1860) beskrev i 1922 disse første homoseksuelle, som siden hans første ungdom i 1870'erne havde beskœftiget hans tanker og fristet hans pen: »Indenfor de yngre, akademiske, litterœre og kunstneriske kredse, hvortil jeg dengang hørte, fœrdedes mœnd af et for en opmœrksom iagttager umiskendeligt, ejendommeligt vœsen, der pegede mod det feminine«.23 Markman var 10-20 år œldre, og for ham måtte 1870'ernes og navnlig 1880'ernes stadig voldsommere diskussion om kønsdriften og om sœdelighedssporgsmålet vœre fremmedartet. Han var for gammel til at blive moderne; fodt lidt for tidligt til at blive en rigtig »moderne homoseksuel «. Om han var pederast, vides ikke. Som student i 1860'erne tilhørte han - som man senere sagde om ham - »tredsernes akademiske overgangstype «.24

Selv om det er tydeligt, at der fra 1870 'erne eksisterede en sœrlig slags mennesker, var der ikke nogen »vedtaget « betegnelse for dem, forend ordet »homoseksual« i 1890'erne begyndte at optrœde i den medicinske litteratur.25»Forbrydelser«, »sœdelighedsforbrydere«, antydning og omskrivning var til århundredskiftet den altdominerende udtryksmåde i pressen. »Urning « var et ord, som ikke slog rigtigt 
an i Danmark. Det var karakteristisk, at de homoseksuelle i Danmark i det første kvarte århundrede af deres eksistens ikke havde noget nyt navn for sig selv, men antog »sœdelighedsforbryder « og »kriminel«, talte om »sygdom « og »forbandelse«. Alligevel forekommer det forsvarligt at betegne en rœkke personer fra denne tid som »homoseksuelle«. De havde en lang rœkke af de personlighedsmœssige og sociale trœk, som kendetegnede den moderne homoseksuelle: En sœrlig barndom, en medfodt og permanent degenereret tilstand, en kvindelig sjœl, en tvetydig dobbelthed i deres vœsen, en modstrid mellem det ydre og det indre, en tragisk skœbne, et livsvilkår og en livshistorie i alvorlig social konflikt, kunstneriske anlœg, slappede nerver, en tendens til at udvandre til Amerika og til at begå selvmord. Alle var de ugifte, bymennesker, enkelte kom i retsvœsenets og pressens søgelys, og de var (nœsten) usynlige.26

Markman kunne som nœvnt ikke blive en moderne homoseksuel, og vi genfinder da også kun nogle af de her nœvnte trœk i hans liv og person. Hertil kommer, at kildematerialet til dokumentation af denne usynlige side af Carl Markmans liv er så svagt, at spørgsmålet om hans homoseksualitet forbliver et spørgsmål. »Usynlige« mennesker efterlader sjœldent så gode kilder til historikeren, som Pontus Wikner gjorde det, hverken om deres eventuelle genitalseksuelle aktiviteter eller om deres bevidsthed som homoseksuelle, og historien om den usynlige homoseksuelle må blive lige så tvetydig og dunkel som det liv, den vil skildre.

Offentligt kendte homoseksuelle var der kun ganske få af. En enkelt i offentligheden berygtet og eksemplarisk homoseksuel mand - og ingen homoseksuelle kvinder - synes at have vœret nok til at bekrœfte eksistensen af en truende og forgrenet verden af sœelig depravation og sygelig seksuel abnormitet. I 1870'erne og 80'erne tilfaldt denne rolle forfatteren Martin Kok (født 1850), som i 1øbet af 1890'erne afløstes af den langt mere berygtede (og langt mere talentfulde) forfatter Herman Bang (født 1857). Kun ganske få homoseksuelle blev genstand for myndighedernes undersøgelse og pressens opmœrksomhed på en måde, der afslørede deres identitet som homoseksuelle. Det karakteristiske for rollen som homoseksuel i denne periode var netop, at den homoseksuelles identitet som homoseksuel var skjult og usynlig. Men ikke totalt skjult og ikke totalt usynlig; til at vœre homoseksuel krœvedes, at mindst et menneske - den pågœldende selv - vidste det, eller at nogen anden hœvdede det.

\section{Hvem var Carl Markman?}

Carl Josef Markman er nu en glemt forfatter, som heller ikke i sin samtid fandt synderlig succes. I de syv bind med romaner, noveller og komedier, som han skrev, finder man ikke noget engagement, der kan forklare, hvorfor han overhovedet gav sig af med at skrive.

Han var adjunkt på Herlufsholm Kostskole i gymnastik og fransk. En af hans elever, forfatteren Palle Rosenkrantz, betegnede ham som »noget af et mislykket Geni«. Men der var noget i Markmans personlighed - »noget der interesserede «. Det hed sig, at han var fritœnker:

Hans ansigt mindede om de gamle Hermer af Sokrates, han var lille og svœr (...) og en underlig Blanding af Brutalitet og Aandsaristokrati, ikke lidet lapset i sin Fremtrœeden med elegant, langskødet, graa Frakke og graa Hat, ofte vittig, stundom haanende, men altid med en vis Understrøm af Utilfredshed med sin Lod og Gerning.27

Markman sluttede sine romaner med banale og konventionelle konklusioner. Tilsyneladende lykkelige slutninger, men mœrkbart, at disse filistmse og ufarlige slutreplikker, som foregiver at samle romanens ledemotiv op i nogle få ord, også af forfatteren må vœre ment som fromme platituder: »Hjem og passe sin Butik « (Ariel, 1881) - »Det ender dog med, at man giver sig til at bestille noget « (Studenter, 1881). Markman ansås af sin samtid for at have uortodokse meninger; var han forhindret i at formulere det, som egentlig lå ham på sinde?

Markmans sidste bog, romanen »Poul Breinum« (1891), er en livshistorie om en lille dreng, som følges fra 3års alderen, indtil han som voksen mand og erhvervsdrivende selv har en Søn på 3 år. Denne almindelige hverdagshistorie ender med en samtale mellem faderen og Sønnen, der har overhørt en 
politisk diskussion, hvor det er blevet sagt, at vi er kaput her tillands - vi erfœrdige - vi kan ikke mere. Den lille dreng spørger sin far, om det er sandt. »Breinum rejste sig, tog sin Søn paa Armen og traadte hen til Vinduet med ham. - »Nej, det er ikke sandt, min Dreng. Se dig kun om i Verden. Vi kan lidt endnu «. Det var ment som en optimistisk slutreplik, men den overbeviser ikke. Skrevet af en mand, der gik for hverken at have rettroende meninger eller for at vœre diplomat er det ikke blot ligegyldigt og konformt, men også opgivende.28

Markmans skildringer af unge mœnd, hvis søgen efter ståsted og lyst til bedrifter i fmste omgang fœnger hos lœseren, ender i en uforklarlig bitter tone, og lœseren får ikke undervejs hjœlp til at forstå, hvorfor hovedpersonens vellykkede integration i erhvervsliv og familie omgives af så ringe entusiasme fra forfatterens side. Det bemœrkede man også i samtiden, og det omtaltes i en nekrolog som »den aparte Ejendommelighed, at han, når han har skrevet sig op, er blevet varm og virkelig har afvundet Lœseren Interesse, ligesom hœlder en Skylle koldt Vand over ham, idet han pludselig falder ned fra Højden og ødelœgger hele det gode Indtryk ved banale Deklamationer eller ligesom paa en Gang at opgive Evred «.29

Markmans biografer er enige om at rose ham for hans gode dialoger og skarpe iagttagelser.30 Hans mangeårige ven, boghandleren Andreas Dolleris, har i sin lille biografi, »Carl Markman. En biografisk Pennetegning « (1910), fremhœvet et eksempel på hans iagttagelsesevner. Det er en scene i novellen »Have-Døren« (1883), og Dolleris antager, at den må vœre selvoplevet.31 Novellens inkarnerede ungkarl - »han stod alene i Verden, som man siger om de ulykkelige, der ikke have bestemte Personer at spise til Middag med hver Dag«32 - iagttager oppe fra Christianshavns Vold en flok skoledrenge på Kigkurens Badeanstalt. Scenen, der er ud en forbindelse med novellens hovedtema - en almindelig forlovelseshistorie - er levende og skarpt tegnet og ledsages af ungkarlens bemœrkninger om, hvor uœstetisk og uinspireret proletarisk badeanstaltens drenge opfører sig i sammenligning med, hvad en tilsvarende scene ville have vœret $i$ en palœstra i antikkens Athen. Dette tilskriver han badeanstaltens uinspirerende placering og mangel på arkitektonisk monumentalitet. Omplantningen i fantasien af en københavnsk badeanstalt i 1880' erne til en hellensk palœstra med dens smukke og - måske underforstået - disponible atleter er en dagdrøm. Afspejlede ungkarlens surhed og nedladenhed, at Markman havde opgivet drømmen om »det grœske«?

Markman var lœrer på Herlufsholm 1873-1887. En af hans elever har skildret hans virke som gymnastiklœrer:

Han kom som en Reformator. Han vilde vœre den, der sørgede for Drengenes legemlige Opdragelse. (...) Gymnastikken blev et Hovedfag. (...) Vi, der var smaa Drenge, da han kom til Skolen, var egentlig bange for ham. Da vi blev œldre, var han den af Lœrerne, vi holdt mest af. Vi forstod da, at han ingenlunde var en brutal, bomert Soldat.33 At han tvœrtimod var den fordomsfrere og finere følende af vore Lœrere. At han var en Poet - et Lyst og vittigt Hoved. At han mere end nogen andre forstod Ungdommen og Ungdommens Krav. At han som Følge deraf var den toleranteste, den mest overbœrende, den hjœlpsomme, naar det kneb.34

Inden Markman kom til Herlufsholm, havde han en rœkke lœrerstillinger i provinsen, men han levede bedst i storbyen og betegnede sig selv som »indœdt Københavner«.35 Han var vokset op på Bœrnerholm, og han tilbragte årene efter afskeden fra Herlufsholm i København.

\section{Beskyldningen}

Om årsagen til, at Markman allerede som 47årig, i 1887, trak sig tilbage fra stillingen som adjunkt ved Herlufsholm, er der givet forskellige forklaringer. Det skete i forståelse med skolens ledelse, som gav ham en pension, han egentlig ikke var berettiget til. Dollens antog, at han var blevet trœt af at vœre gymnastikinspektør og ikke kunne holde faget på sin tidligere højde, og at det måske var en medvirkende årsag, at han betragtedes som en mand med kœtterske meninger. Hovedgrunden angav 
Dolleris at vœre hans trang og lyst til at leve af sit forfattertalent. Palle Rosenkrantz betegnede hans afskedigelse som $\gg$ nok hans Livs Tragedie «.36

I et brev til forfatteren Karl Larsen kunne den jœvnaldrende homoseksuelle forfatter, Joakim Reinhard (1858-1925), berette om en anden grund: » (...) Forleden meddeltes det i bladene, at en ualmindelig afholdt discipel på Herlufsholm var forsvundet og senere fundet død. Han havde skudt sig i en skov. Samtidig meddeltes det andetsted, at adjunkt Markman (forfatteren) havde taget sin afsked og flyttede til København. Disciplen var 17-18 år, hed Carl Moltke (faderen amtm i Hjørring). Froberg kendte ham og sagde, han var ualmindelig elskvœrdig. Der var et forhold mellem ham og Markman, som blev opdaget, og drengen kunne ikke udholde dette «.37

Den 17årige elev på Herlufsholm Skole, Frederik (»Fritz«) Ludvig Moltke, skød sig den 8. juni 1887. Der var ingen tvivl om, at det var selvmord, omend motivet forblev ukendt. Han indkøbte en revolver i Nœstved, gik ud i Kalby Ris Skov og skød sig først i tindingen og derefter i brystet. Han efterlod to afskedsbreve, et til sin mor og sin søster,38 og et til sin skolekammerat, Emil Stabell. Det sidste blev fremlagt i retten ved det efterfølgende forhør, og det nœrmeste i retning af en forklaring af motivet var ordene: »Hellere dø end leve som et characterløst Menneske«.39

Fritz Moltkes selvmord var komplet uforståeligt for dem, der kendte ham. Distriktslœgen, som foretog ligsynet, havde kendt ham fra barn og opfattede ham som et opvakt og elskvœrdigt ungt menneske, der mens han gik på Herlufsholm, var kommet meget i hans hus - bortset fra den sidste tid. Distriktslœgen havde »aldrig hørt nogen Yttring af Afdøde, som tydede på Livslede, og er vis paa, at Afdøde, der var en kjœrlig Søn, maa have gjennemgaœt en forfœrdelig Sjœlekamp for at begaa Selvmord af Hensyn til den Sorg, han derved beredte sin Moder«. Dommeren, der ledede forhøret, havde også kendt Fritz Moltke, og protokollerede, at han var enig med distriktslœgen om, at Fritz Moltke bestemt ikke var drikfœldig. Distriktsleegen tilføjede, at der ikke var »Spor af Sygdom i Kjønsdelene eller Tegn paa sensuelle Udskejelser«.40

Fritz Moltkes klassekammerat og gode ven, den 15 1/2årige Emil Stabell, kunne i retten kun fortœlle, at Fritz Moltke aldrig havde sagt noget om, at han var trœt af at leve, eller at han ville tage livet af sig. Men siden Pinse havde han lagt mœrke til, at Fritz Moltke havde vœret alvorlig og noget tungsindig. Emil Stabell kunne heller ikke forklare, hvorfor Fritz Moltke skulle anse sig selv for at vœre et »characterløst Menneske«.41

Emil Stabell, som i retten erklœrede sig som fritœnker og ukonfirmeret, blev også udspurgt om et eventuelt religiøst motiv, som kunne vœre fremkaldt af samtaler med lœrere eller sœttes i for bindelse med lœsning af visse bøger - Rousseaus »Bekendelser« blev nœvnt som netop lœst af Fritz Moltke. Rektor Forchammer, der var blevet noget pikeret over dette forhør, som han mente gik skolen for nœr, afviste over for Herlufsholms forstander, fhv. konseilsprœsident C.C. Hall, at der kunne vœre tale om »den allerfjerneste Forbindelse« mellem lœsningen af Rousseau og Fritz Moltkes død.42 Hall var af ganske samme mening, og i et brev til Forchammer - konciperet af Sønnen, Gluf Hall, som i praksis varetog faderens forstanderforretninger - konkluderede han, at Fritz Moltkes død hverken skyldtes skolesorger eller familiesorger; hans selvmord var en uforklarlig gåde. 43

Selvmordet kan ejheller forklares med den af Froberg til Reinhard kolporterede oplysning om, at et forhold mellem Fritz Moltke og Markman var blevet opdaget, og at Markmans afsked havde forbindelse med dette. Allerede tre uger før selvmordet skrev rektor Forchammer til Oluf Hall, at Markman igen var begyndt at tale om at tage sin afsked. Forholdet mellem dem havde leenge vœret dårligt, og Forchammer ville nødig beholde Markman på skolen »til han bliver aflœgs, og nœgter De ham nu en Pension, risikerer vi at beholde ham paa ubestemt Tid, og da bliver Enden vœrre end Begyndelsen«. Markman havde leenge irriteret Forchammer ved »sin bryske for ikke at sige brutale Optrœeden«; i øvrigt var han taktløs og pustede til ilden i konflikter mellem rektor og lœrerne. Kort før pinse, den 22. maj 1887, fremsendte Forchammer Markmans ansøgning om afsked med sin egen påtegning om, at den blev imødekommet.44 Intet - udover Reinhards brev - tyder på en forbindelse mellem Markmans afsked og Fritz Moltkes selvmord to uger senere. 
At Reinhards brev til Karl Larsen hvilede på et usikkert grundlag, viger også hans fejlagtige angivelse af Fritz Moltkes fornavn som »Carl«. Men når Froberg mente at vide - og Reinhard viderebragte til Karl Larsen - at selvmordet og afskeden skyldtes et opdaget forhold mellem Markman og Fritz Moltke, kan det skyldes, at Froberg og Reinhard kombinerede disse to begivenheder med en viden eller en formodning om, at Markman var homoseksuel. Alligevel er der ingen grund til at tro, at Froberg og Reinhard skulle vœre bedre underrettet om Markmans homoseksualitet, end de var om hans afsked fra Herlufsholm og om Fritz Moltkes fornavn og selvmord.

\section{Beskyldningens indhold}

Den første i Danmark, som offentligt udpegede og stemplede en mand for at have sex med en anden mand, var forfatterinden Dorothea Biehl. I 1781 valde hun sensation ved i novellen »Den falske Ven« at antyde, at der mellem hendes personlige fjende, Det kgl. Teaters direktør, Wilhelm von Warnstedt, og den 14årige balletdanser, Frederik Schwarz, var en »skœndig fortrolighed, for hvilken der faldt Ild ned af Himmelen til at fortœre Sodoma og Gomorra«.45 Mellem Markman i 1880'erne og Wilhelm von Warnstedt i 1780'erne er der den lighed, at påstanden om deres seksualitet hviler på et utrovœrdigt eller i bedste fald meget spinkelt grundlag. Dorothea Biehl kunne lige så lidt som Reinhard vide noget konkret om, hvilke genitalseksuelle handlinger der havde fundet sted eller med hvem. At karakterisere Warnstedt og Markman som »homoseksuelle« ville i begge tilfœlde vœre at drage slutninger om disse mœrnds seksualitet på grundlag af genitalseksuelle handlinger, som der intet vides om.

Forskellen imellem disse to historier er den, at påstandene om »seksualitet «ikke er den samme, men adskilt af et hundrede års historiske udvikling i opfattelsen af, hvad der skal forstås ved »seksualitet « imellem mœnd - forskellen mellem oplysningstidens sodomi og moderne tids homoseksualitet. Sodomi var på Warnstedts tid noget, der forudsatte en ganske bestemt genitalseksuel, strafbar handling (anal penetration). Hvis den ikke havde fundet sted, var den pågœldende ikke sodomit eller - som man sagde i 1800-tallets første halvdel - pœederast. Hans forhold til mœnd i øvrigt var irrelevant for spørgsmålet om hans »seksualitet«. Anderledes på Markmans tid, i 1880'erne; en homoseksuel mands seksualitet var ikke nødvendigvis genitalseksualitet, men en bevidsthed - andres eller egen - om det pågœldende menneskes vœsen, lyster og livsforhold i meget bred forstand. En sådan bevidsthed kunne medføre, at den pågœldende blev betegnet som homoseksuel - af sig selv eller af andre - og dermed fik eller antog rollen som homoseksuel. I det danske samfund forelå rolle først, da Markman var blevet midaldrende. Med Reinhards »beskyldning « kommer Markman til at stå som en historisk overgangstype i et spœndingsfelt mellem den œldre og i 1880'erne forœldede rolle som »pœderast« (hvad han efter alt at dømme ikke var) og den langt mere omfattende og temmelig diffust definerede moderne rolle som »homoseksuel «. Det sidste angå nogle yngre homoseksuelle mœnd i hans samtid ham for at vœre. Var Markman »en Pontus Wikner« uden bekendelsesskrift? 47

\section{Carl Markmans usynlige indre}

Andreas Dalleris, der vel stod Markman ganske nœr, erkendte, at han aldrig kom til at kende Markman rigtigt, og at det var vanskeligt at skildre hans livsfølelse. Markman åbnede sig aldrig, selv ikke for sine nœrmeste fortrolige og bedste venner. Sit sjœleliv og sine hjerteanliggender søgte han at skjule for omverdenen. At Markman skulle have vœret forelsket i datteren på en gård, hvor han havde vœret huslœrer, betegnede Dolleris som »et Sagn«.48

Da netop et forfatterskab som det, Markman strœbte efter, krœvede tillid til egne livserfaringer, så ligger heri måske en forklaring på, at Markman ikke lykkedes som forfatter. Formodentlig kunne han netop ikke bruge sine egne livserfaringer i sit forfatterskab, og det er ikke mœrkeligt, at hans konforme holdninger, som de kom til udtryk i hans bøger, virkede overfladiske og uinteressante, også på dem, der delte dem. Markmans talent kan ikke sammenlignes med de samtidige, men ca. 15 år yngre forfattere, Herman Bang og Oscar Wilde, eller med den 30 år yngre Marcel Proust, som i vidt omfang udnyttede og 
lod sig inspirere af den indsigt i mennesker og samfund, som rollen som homoseksuel gav dem til at udvikle en sœrlig dekadent œstetik. Markman tilhørte en årgang og dermed en tid, som endnu ikke havde den bevidsthed om homoseksualitet, som tillod ham at opfatte den som grundlag og udgangspunkt for sœrlige livserfaringer med en sœrlig form for gyldighed.

Det sagdes om Markman, »at han savnede den Dybde i Sjœlen, der er Grundlag for Originalitet «49 men vilkåret var, at han for overleve måtte skjule det for omverdenen, der måske foregik i hans indre, og lade sin trang til at udtrykke sig få prœg af overfladiskhed og manglende engagement. Han måtte formentlig leve i et indre eksil og tage til efterretning, at ingen ville bryde sig om synet, hvis han lod dem se dybere i sin sjœl og lagde denne dybde til grund for kunstnerisk skaben. Vennen, Andreas Dolleris erkendte, »at Markman ikke ejede den Lykke, der bestaar i Harmoni mellem Manden og Poeten« og citerede: »Tidt øjnene tindre, og Lœberne le til Skjul for et Indre, som Ingen maa se«.

Selv var Markman klar over, at denne »Harmoni mellem Manden og Poeten« ikke kunne blive hans. Da Dolleris sendte ham et komplimenterende digt, hvis pointe var, at Markman faktisk ejede denne harmoni, svarede Markman med et ironisk og spottende epigram:

Som bedste Bevis paa, at Skuddet har rammet, her Neger-Vrœlet, hør Hundeglammet.

Dolleris troede, at Markman dermed tog hans kompliment for gode varer,50 men Markmans svar tyder snarere på, at han vidste, at det ikke passede, men heller ikke ville gå nœrmere ind på emnet.

Markman skrev en lang rœkke vœrdsatte lejlighedssange og viser, og han gik med tanker om at udgive en samling digte under pseudonym - ikke lejlighedsviserne, men andre digte. Som prøve citerede han flere gange for Doneris et lille digt. Dolleris fandt linjerne »besynderlige«:

Et Kys er Eros Kaktus. Hvoraf følger, at der maa passes paa ham al den Stund, han ikke Flyvelysten dølger.

Ja, ømt og kjœrligt, Mund mod Mund, et Kys er en Sejlads paa milde Bølger paa - Svendborg Sund.51

Kan det tœnkes, at Markman med dette digt sendte en meget diskret prøveballon op for at se, hvordan Dolleris reagerede? Et kys, der karakteriseres som »Eros Kaktus« er kun forståeligt, hvis den der kysses, er en voksen mand.52 (...) »ikke Flyvelysten delger« hentyder måske til en tilskyndelse til at skjule og undertrykke de følelser, der er forbundet med Eros Kaktus. En sådan tolkning havde Dolleris åbenbart ikke $\varnothing j \mathrm{je}$ for. Digtsamlingen blev aldrig udgivet. Markmans breve og papirer blev tilintetgjort straks efter hans død.53

»Carl Markman var ingen lykkelig Mand; han savnede den Harmoni i Sjœlen, der skaber Lykke - han savnede den midtpunktsegende Kraft«. Han »var i sit Indre aldrig munter«.54 Dolleris gav sig ikke ud for at have forstået den gådefulde Markman. Var den brik, som Reinhard havde til puslespillet - at Markman var homoseksuel - den, som Dolleris manglede? Tanken synes ikke at have strejfet Dolleris. Markmans indre er skjult, hans eventuelle genitalseksualitet vides der intet om, men blandt samtidens homoseksuelle gik han for at vœre homoseksuel.

\section{Noter}

Henvisninger til almene forhold i bøssehistorien og i dansk historie er summariske; der henvises til forfatterens bog, Månens kulфr. Studier i dansk bøssehistorie 1628-1912, som udkommer i begyndelsen af 1990. Historien om Carl Markman er ikke medtaget heri. Jeg skylder Herlufsholm Skole tak for at have fået adgang til skolens arkiv. 
1. Abrams 1896 s 42-43. Det ville stride imod disse erindringers kontekst, at opfatte skildringen af HeeghGulbergs og Wengels samliv som en antydning af et seksuelt forhold. Jeg skylder cand. mag. Ole Nørlyng tak for henvisningen til denne kilde.

2. De vigtigste af disse modeller var Heinrich Hösslis model om »platonisk kønskœrlighed « som »et rent videnskabeligt anliggende« og »en naturlig kœrlighed« (1836); H.C. Andersens »forlovelses «-model (1846); J.L. Caspers psykologiske model (1852); Arthur Schopenhauers model om pœederasti med henblik på artens sunde videreførelse (1859); Walt Whitmans maskulint-demokratiske model om venskabet (1860); K.H. Ulrichs' emancipatoriske urninge-model (1864); C.F.O. Westphals neurologiske model om den kontrœrseksuale fornemmelse som et tegn på degeneration (1869).

3. Behrend/Topsøe-]ensen 1937 vol VI s 25. Kertbeny-affœren er gennemgået i Topsøe-]ensen 1969 s 337-342.

4. Behrend/Topsøe-]ensen 1937 vol II s 378 (H.C. Andersen til Edvard Collin, Dresden 26.10.1860).

5. Gad 1974 s 425-426 (dagbogsnotat 31.8.1860).

6. Gad 1974 s 444 (dagbogsnotat 4.10.1860).

7. Som note 3 .

8. Herzer 1985.

9. Det er ikke sikkert, at Kertbeny selv var homoseksuel I et brev fra 1868 til opfinderen af ordet »urning «, Karl Heinrich Ulrichs, og i de anonyme pjecer fra 1869, som han formodentlig var forfatteren til, lod han forstå, at han ikke skrev som »en såkaldt urning«; Herzer 1985 s 11-12. Herzer 1987.

10. Berg 1880 s 604 note.

11. Hafstrøm s 90.

12. Pontoppidan s 511.

13. Pontoppidan s 513.

14. von Rosen 1980, 1985.

15. Jvf. Weeks 1981 s 81.

16. Foucault 1978 s 52.

17. Vort Folks Skœndsel 1911.

18. Frœnkel 1912 s 5.

19. Den samtidige opinion delte sig i en konservativ retning, som opfattede homoseksualitet som en last, der bredte sig ved erhvervelse og forførelse, og derfor kunne og burde førhindres - og en mere mod videnskaben orienteret opinion, der opfattede homoseksualitet som medfødt og som noget, der nu var blevet opdaget, men altid havde eksisteret og ikke kunne hindres.

20. Herman Bang til A.P. Holst 2.3.1893, citeret efter Bjørnby 1986 s 223.

21. Bang 1922.

22. Wikner 1971 s 15, 18, 25, 56, 59 (Wikners fremhœvelser). Det er karakteristisk for den isolation, i hvilken Wikner nåede frem til erkendelse af sit eget vœsen, at han - juridisk ukorrekt - betegnede gensidig onani som sodomiteri. Han navngav i øvrigt ikke sin sœrlige natur.

23. Larsen 1922 (forord).

24. Dumreicher 1934 s 87, der i øvrigt karakteriserer Markman som »en burchikos studiosus perpetuus«. 25. »Homoseksual« og afledninger deraf forekommer formentlig for første gang på dansk i 1892;

Tandem 1892 s 217; Geill1893 s 469.

26. For beskrivelser af den moderne homoseksuelle, se Bech 1983 s 53-67; Bech/Lützen 1986 s 43-46; Bech 1987.

27. Rosenkrantz 1927 s 50-51. Rosenkrantz var elev på Herlufsholm 1881-84. 28. Nekrolog af Peter Nansen i Politiken, her refereret efter Dolleris 1910 s 73. 29. Georg Lütken i Allers Lexikon, citeret efter Dolleris 1910 s 71-72.

30. Dumreicher 1938 s 333-34.

31. Dolleris 1910 s 53.

32. Markman 1883 s 2. 
33. Markman var frivillig i krigen i 1864 og blev reserve1øjtnant 1866.

34. Dolleris 1910 s 39-40, som ikke angiver kilden.

35. Dolleris 1910 s 45.

36. Rosenkrantz 1927 s 51.

37. Reinhard til Karl Larsen 6.7.1887, $\mathrm{Ny} \mathrm{kgl.} \mathrm{Samling} \mathrm{4630,} \mathrm{4}$, Det kgl. Bibliotek, Kbh. Lœrer E.C. Froberg (f. 1839) var en bekendt af Reinhard; jvf. Petersen 1884 s 100.

38. Faderen, amtmand A.F. Moltke, var død 1886.

39. Rektor J.N.G. Forchammer til forstander for Herlufsholm, C.C. Hall 10.6.1887, Kopibog og Journal for Skrivelser udfœrdiget af Rektor paa Herlufsholm 1881-94, Herlufsholms arkiv, Nœstved.

40. Politiprotokol1885-91 fol. 334-38.

41. Politiprotokol1885-91 fol. 334-38.

42. Forchammer til Hall 16.6.1887, Kopibog og Journal for Skrivelser udfœrdiget af Rektor paa

Herlufsholm 1881-94, Herlufsholms arkiv.

43. Oluf Hall til Forchammer 18.6.1887 (brevkoncept), Oluf Halls privatarkiv (nr. 5523) B, Rigsarkivet, Kbh.

44. Forchammer til Oluf Hall 18., 20., 22. og 26.5.1887, Oluf Halls privatarkiv (nr. 5523) A.I.3.a,

Rigsarkivet, Kbh.

45. Biehl 1781 s 88. Biehl 1909 s 225, 234. Birch 1793 s 194. 46.

Påstanden om, at Warnstedt var »homoseksuel«, er senere fremført af flere personalhistorikere. De

bygger imidlertid udelukkende på Dorothea Biehls hadefulde novelle. Jvf. Ørbrek 1936 s 9-11, 60.

Neiiendam 1937 s 160. Der kendes ikke andre kilder, som kan bekrœfte påstanden, som heller ikke synes at vœre blevet accepteret i samtiden. Den kildekritiske tilbagevisning af Biehls novelle og

Reinhards brev som belœg for, at der har fundet genitalseksuelle handlinger sted, betyder naturligvis, at der ikke kan drages slutninger deraf og ikke kan bygges videre på dette grundlag.

47. Pontus Wikner begik - som det fremgår af hans selvbekendelser (jvf. note 22) - ikke

sodomi/pœderasti. Det afgørende for hans kønslige selvforståelse og for eftertidens opfattelse var hans lyster og følelser. Der var diskrete udslag heraf i hans offentliggjorte litterœre produktion, og for skarpe iagttagere i samtiden var der en mistanke.

48. Dolleris 1910 s 7-8,20,79.

49. Dolleris 1910 s 78.

50. Dolleris 1910 s 48-51.

51. Dolleris 1910 s 34. Dolleris gengiver digtet efter erindringen.

52. »Kaktus« skal for den her fremhœvede tolkning opfattes som et attributiv: »Kaktus-eros« eller »Eros med kaktus «.

53. Dolleris 1910 s 80.

54. Dolleris 1910 s 77, 79.

\section{Litteratur}

Arthur Abrams: Minder fra min Studentertid, Kbh. 1896.

Herman Bang: Gedanken zum Sexualitätsproblem, herausg. von Dr. Wasbutzki, Bonn 1922.

Henning Bech: »Mellem mœnd « in Kontext nr. 45, Kbh. 1983.

Henning Bech: Når møend mødes - Homoseksualiteten og de homoseksuelle, Kbh. 1987.

Henning Bech og Karin Lützen: Lyst eller Nød? Kvinders og monds homoseksualitet - Redegфrelse for

nogle synspunkter og resultater $i$ videnskabelig litteratur, Kommissionen til belysning af

homoseksuelles situation i samfundet, Kbh. 1986

C. Behrend og H. Topsøe-Jensen (udg): H.C Andersens Brevveksling med Edvard og Henriette Collin, Kbh. 1937.

Rudolph Berg: »Beretning fra Almindelig Hospitals 2den Afdeling (for veneriske- og Hudsygdomme) for 1879 « in Hospitalstidende, Kbh. 1880 s 604 note. 
C.D. Biehl: »Den falske Ven eller hertil og ikke lœngere« in Moralske Fortœllinger II, Kbh. 1781.

C.D. Biehl: »Mit ubetydelige Levnetsløb« in Louis Bobé (udg): Interiører fra Kong Frederik den Femtes Hof, Kbh. 1909.

H.J. Birch: Billedgallerie for Fruentimmer I, Kbh. 1793.

Pål Bjørnby: »The Prison House of Sexuality: Homosexuality in Herman Bang Scholarship« in Scandinavian Studies 58, Madison 1986.

Andreas Dolleris: Carl Markman - En biografisk Pennetegning, Kbh. 1910.

Carl Dumreicher: Studenterforeningens Historie I, Kbh. 1934. Carl Dumreicher in Dansk biografisk

Leksikon Bd. 15, Kbh. 1938.

Michel Foucault: Seksualitetens historie I- Viljen til viden, Kbh. 1978

E. Frœnkel: Kriminalister og Prostitution, Kbh. 1912.

Tue Gad: H.C Andersens Dagbøger IV, Kbh. 1974.

Chr. Geill: »Anm. af Kn. Pontoppidan - Psykiatriske Forelœsninger og Studier I-II, Kbh. 1892-93« in Ugeskrift for Loger, Kbh. 1893.

S.M. Hafstrøm: Om Sœdelighedsforholderne i det danske Folk særlig Bondestanden og Almuen, Kbh. 1888 s. 90.

Manfred Herzer: »Kertbeny and the Nameless Love« in Journal of Homosexuality 12, New York 1985.

Manfred Herzer: »Ein Brief von Kertbeny in Hannover an Ulrichs in Würzburg « in Capri. Zeitschrift für schwule Geschichte 1, Berlin 1987.

Karl Larsen: Daniel-Daniela, Kbh. 1922.

Carl Markman: Have-Dфren, Kbh. 1883.

Robert Neiiendam: Anm. af Ørbœk 1936 in Personalhistorisk Tidsskrift 10. Rk 4, Kbh. 1937.

Anders Petersen: Den jonstrupske Stat, Kbh. 1884.

Kn. Pontoppidan: »Pervers Seksualitet - En klinisk Forelœsning« in Bibliothek for Løger, Kbh. $1891 \mathrm{~s}$ 511.

Wilhelm von Rosen: »Venskabets Mysterier - Om H.C. Andersens roman »O.T.«, hans forelskelse i

Edvard Collin og »Den lille Havfrues« forløsning« in Anderseniana 3. rk. III, Odense 1980.

Wilhelm von Rosen: »H.C. Andersens forelskelse i Ludvig Müller« in Kritik 73, Kbh. 1985.

Palle Rosenkrantz: Tre Aar paa Herlufsholm, Kbh. 1927.

»Tandem«: »Den kontrœre Sexualfornemmelse - Fragmenter til Oplysning « in Bibiliothek for Loger,

Kbh. 1892

H. Topsøe-Jensen (udg): »H.C. Andersens Breve til Carl B. Lorck« in Fynske Studier VIII, Odense 1969 s 337-42.

Jeffrey Weeks: »Discourse, desire and sexuel deviance - some problems in a history of homosexuality « in Kenneth Plummer (ed): The Making of the Modern Homosexual, London 1981 s 81.

Pontus Wikner: Psykologiska självbekännelser, Stockholm 1971.

Vort Folks Skondsel (pjece), Kbh. 1911.

W. Ørbœk: Hans Wilhelm von Warnstedt. Officeren-Theaterdirektøren-Diplomaten - En

personalhistorisk og tidshistorisk Skildring, Kbh. 1936.

\section{Arkivalier}

Kopibog og Journal for Skrivelser udfœrdiget af Rektor paa Herlufsholm 1881-94, Herlufsholms arkiv, Nœstved.

Politiprotokol 1885-91, Tybjerg Herred, Landsarkivet for Sjœlland, København. Oluf Halls privatarkiv (nr. 5523). Rigsarkivet, København.

Karl Larsens privatarkiv, Ny kgl. Samling 4630, 4º Det kgl. Bibliotek, København. 


\section{Om forfatteren}

Wilhelm von Rosen (f. 1941), cand. mag. (historie), er arkivar i Rigsarkivet, København. Han var aktiv i Bøssernes Befrielsesfront 1971-77 og medredaktør af PAN 1976-83. Han har blandt andet publiceret Bøssekampens politik (1979), Gay Life and Gay Writers (m. Vagn Søndergaard i 1979) og artikler og afhandlinger i danske og udenlandske tidsskrifter og bøger. 